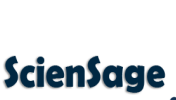

Journal of Advanced Scientific Research

Available online through https: / / sciensage.info
ISSN: 0976-9595

Review Article

DOI: $10.55218 /$ JASR. 202213107

\title{
TRANSFORMING PLANT SECONDARY METABOLITE PRODUCTION THROUGH THE APPLICATION OF PTC AND ELICITOR TECHNOLOGY
}

\author{
Ruchi Gupta**1, Deepak Jain ${ }^{2}$ \\ ${ }^{1}$ Smriti College of Pharmaceutical Education, 4/1 Pipliya Kumar, MR-11, Dewas Naka, Indore, Madhya Pradesh, India \\ ${ }^{2}$ Department of Pharmaceutical Sciences, Mandsaur University, Mandsaur, Madhya Pradesh, India \\ *Corresponding author:ruchirocks87@gmail.com
}

\begin{abstract}
Plant tissue culture is an in-vitro culture technique for the production of plant cells. It is a very good, attractive and cost effective technique for the production of secondary metabolites. Plants produce counter response against the environmental threats like bacteria, virus, fungi, insects etc. and some physically harsh environmental conditions such as salinity, temperature, exposure to ultra violet radiation. Plants produce responses against the signals obtained through sensors, receptors and defense responses which are stabilized against these stresses. These trigger responses elucidate the production of secondary metabolites (alkaloids, glycosides, tannins, resins and tannins) which are useful for the survival, persistence and competitiveness of the plant. These secondary metabolites are useful in various areas such as food additive, pharmaceuticals, cosmeceuticals and therapeutic industries. The present review discusses about the types of biotic (physical, chemical and hormonal elicitors) and abiotic elicitors (lipopolysaccharides, polysaccharides, oligosaccharides, protein, complex composition and oregano extract). These elicitors are used for enhancing the yield of secondary metabolites in the medicinal plants which are useful in various area of research and are also useful in different industries.
\end{abstract}

Keywords:Elicitors, Biotic, Abiotic, Secondary metabolites.

\section{INTRODUCTION}

Plants have played important role in ancient traditional system as well as in modern medicinal research. Many people rely on herbal medicines for the treatment of different diseases and wellness of the health [1-2]. Plants contain a lot of miraculous medicinal active phytoconstituents which are very important in different sectors such as cosmeceutical, nutraceutical and pharmaceutical [3]. Demand of such products is increasing because they do not show any side effects [4]. Plants contain different types of heterogeneous compounds such as medicinally active components which are responsible for the pharmacological and therapeutic activities of the plant. These active phyto constituents also play an important role in the development and growth of the plants [5]. Phyto active constituents also play an important role for the signalling of the molecule and defense system against the pathogens or allergens [6]. Different types of phytoactive constituents in the plants are synthesized by different biosynthetic metabolic pathways such as glycolysis, Krebs cycle, Photosynthesis, Mevalonic Acid
Pathway, Acetate Pathway and Shikimic Acid Pathways [7]. The different active phyto constituents are classified as alkaloid, saponin, steroids, terpenoids, lipids and Eco factors (enzyme cofactor) [8-9] and are produced by different techniques of plant tissue culture (callus and suspension culture). Plant tissue culture is a very good technique for the production of medicinally active phytoconstituents or secondary metabolites [10-11]. Plant tissue culture is an in-vitro biotechnological technique for the culturing of living cells under controlled environmental conditions. Plant tissue culture is extremely vibrant and could be changed according to the required type of culture method (cell culture), aim or objective of the research work. But this in-vitro technique has some disadvantages such as all living cells could not be grown by using it. Plant tissue culture plays an important role in the field of science for the last hundred years and especially from the mid of $20^{\text {th }}$ century after the discovery of somatic embryogenesis and its application is used for innovative and scientific research, for example, in molecular and proteomic approaches. This method is used for the in- 
vitro culturing of cells for the development of the whole plant from a single cell. This method is economically important for the development of the plant. With industrial point of view, it is a highly significant technique for the production of metabolites [12] (Table 1). Plant tissue culture methods and molecular methods work together which plays an important role in altering genetic traits through gene transfer [13].

PCT (Plant Cell Technology) is used for the secondary metabolite production because it is difficult to extract chemicals from the farm plants in situations when any drastic changes occur in the environmental [15].

\section{TYPES OF ELICITORS AND THEIRS APPLICATIONS}

Elicitors are categorized according their origin and nature. It is classified according to their origin as endogenous and exogenous elicitors. It is classified according to the nature of elicitors i.e. abiotic and biotic [16].

\subsection{Endogenous elicitors}

The substances generated within the plant are called endogenous elicitors [17].

\subsection{Exogenous elicitors}

The substances generated outside the plant are called exogenous elicitors [17].

\subsection{Abiotic elicitors}

Abiotic elicitors may be the physical or chemical agents or hormones. Abiotic elicitors most commonly affect the plants to produce the secondary metabolites in plants. But they have shown less effect in PCC (plant cell culture) compared to biotic elicitors [18]. Abiotic elicitors such as metals (heavy), UV light, temperature, saline, drought and hormones are used and have shown different reactions in many key genes, metabolite production, proteins and molecular networks in the plants [19].

Table 1:Different active phyto constituents (secondary metabolites) synthesized by plant tissue culture methods [14]

\begin{tabular}{ccccc}
\hline Alkaloids & Terpenoids & Steroids & Quinones & Phenylpropanoids \\
\hline Acridines & Artemisnin & Bufadienolides & Aloe emodin & Anthocyanin \\
\hline Betalaines & Cucurbitacins & Digoxins & Anthraquinones & Caffeic acid \\
\hline Galanthamine & Diterpenes & Ouabain & Benzoquinones & Coumarins \\
\hline Lobeline & Ginsenosides & Steroidal glycosides & Rhein & Eugenol \\
\hline Trigonelline & Meroterpenes & Physodine & Shokonin & Ferulic acid \\
\hline
\end{tabular}

\begin{tabular}{|c|c|c|}
\hline & Abiotic Elicitors & \\
\hline Physical Elicitors [20] & Chemical Elicitors & Hormonal Elicitors \\
\hline $\begin{array}{l}\text {-Co2 } \\
\text {-Chiling } \\
\text {-Drought } \\
\text { - Extreme temperature shock } \\
\text { - High pressure } \\
\text {-UV } \\
\text {-Salinity } \\
\text { - Mechanical Wounding } \\
\text {-Ozone(O3) } \\
\text {-Altered gass composition } \\
\text {-PEG } \\
\text { - Light intensity }\end{array}$ & $\begin{array}{l}\text { - Inorganic salt } \\
\text { Mercuric Chloride } \\
\text { Copper Sulphate } \\
\text { Calcium Chloride } \\
\text { Vanadyl Sulphate [18] } \\
\text { - Metal ion } \\
\text { Co2+, Fe2+, Al3+, Ag2+, } \\
\text { Ag+, Mn2+, Zn2+, Cu2+ } \\
\text { Pb2+ [18,21] } \\
\text {-Acetic Acid [22] } \\
\text { - Benzothiazole, Silicon [23] } \\
\text { - Ethanol, Ethylene [24] }\end{array}$ & $\begin{array}{l}\text {-Jasmonic Acid } \\
\text {-Methyl Jasmonate } \\
\text {-Methyl Salicylate [25] } \\
\text {-Salicylic acid } \\
\text {-Ethylene [22,26] } \\
\text {-Cytokinin } \\
\text {-Gibberellin GA3 [27] }\end{array}$ \\
\hline
\end{tabular}

Fig. 1:Classification of abiotic elicitors

\subsubsection{Physical elicitors}

UV radiation, thermal temperature and mechanical wounding are the major physical agents. Membrane permeabilization is generally caused by high hydrostatic pressure. It is also a type of physical agents [28]. Some enzymes (inactive) and induced stress responses are reported as physical agents in the plant cells. This is carried out by sealing the cells in sterile bags (pressure20-50 megapascal for 5-10minutes) [28-29]. It is explained by the nine times production of phenolic acids by applying 40 Megapascal pressure in the control in cell suspension culture of Vitis viniferta [28]. Similarly, this procedure is followed for the production of isoflavonoids in cell suspension culture of the soy by 
applying high pressure [29]. Induce defense response is produced in plant cells by applying pulsed electric fields (PEF) which alters the dielectric properties of cell membrane [29-32]. 1.7 times increase in anthocyanin content [32] and 3.6 times increase 3-O-glucosylresveratrol content in cell suspention culture of $V$. Vinifera is observed when compared to the control cells [31]. LEUS (Low Energy Ultra Sound) is another most commonly used technique which is responsible for the induction of shear stress and mechanical damage to the cell. A coustic canitation and micro-streaming methods are used in Low Energy Utra Sound technique [33]. 1.5 to 1.8 times increase in the concentration of taxol by the ultra spund treatment in the cell suspension culture of Taxus chinensis [33], shikonins in Lithospermum erythrorhion [34], anthraquinone in Morinda citrifolia [35], and taxol in Taxus yunnanensis [36] plant cells is done. Some physical agents like $2 \mathrm{~Hz}$ frequency of mechanical vibration is used to increase the production of camptothecin in the callus culture of Camptotheca acuminata in comparision to the control. It has also increased the soluble protein content and SDA (superoxide dismutase activity) [37]. Ultra violet radiation is a type of physical agents which also help in the production of secondary metabolites in Vitis vinifera callus cultures [38] and for the deposition of stilbene in Arachis hypogaea [39]. Red light is used for the production of podophyllotoxin in Linum album [40] and temperature stress is used for the production of anthocyanin production in Melastoma malabathricum [41]. Osmotic stress is used for the production of secondary metabolites and for the development and morphogenesis in the plants [42]. Sucrose is used for the induction of water stress in the plant for the vital production of carbon and energy source in the plants. Osmetic stress is used to enhance the concentration of capsaicin in cell suspension cultures of Capsicum chinensis [43] and of the steviol glycoside content in both suspension and callus culture of Stevia rebaudiana [44].

Drought stress mainly affects the synthesis and accumulation of secondary metabolite contents in the plants. Drought stress is mainly observed in the plant but it varies from species to species [45]. Deficiency of weak water increased the concentration of glycyrrhizic acid content in root of Glycyrrhiza uralensis [45]. PEG (polyethylene glycol) is used as drought stress elicitor agent in date palm callus for enhancing the concentration of proline but it depends upon the concentration of PEG. If the concentration of PEG $(30 \%)$ is higher than the concentration of proline gets declined which indicates a disturbance in physiological system [46]. Extreme temperature negatively affects the growth and productivity of the plants because it is an adverse environmental factor. It also affects the various metabolic processes in the plants which affects the biosynthesis of primary metabolites production [47]. Temperature $\left(17-25^{\circ} \mathrm{C}\right)$ is used for the induction of callus tissues and growth of cultured cells [48]. $25^{\circ} \mathrm{C}$ is an optimum temperature which enhances the production of anthocyanin in cell cultures of Perilla frutescens [49] and strawberry [50].

Table 2:Effect of Physical elicitors on the production of various active phyto-constituents in medicinal plants

\begin{tabular}{ccc}
\hline Elicitos & Plant Species & Compounds \\
\hline High temperature & Panax ginseng, P. quinquefolius & Ginsenoside [51,52] \\
\hline High temperature & Hypericum perforatum & Hypericin, Hyperforin [53] \\
\hline Low temperature & Rhodiola crenulata & Melatonin [54] \\
\hline Low temperature & Medicago sativa & Putrescine [55] \\
\hline Drought & Salix sp. & Flavonoids, Phenolics [56] \\
\hline Water and osmotic imbalance & Hypericum perforatum & Hypericin, Hyperforin [57] \\
\hline PEG & Stevia rebaudiana & Steviol glycosides [58] \\
\hline Water stress & Salvia miltiorrhiza & Salvianolic acid [59] \\
\hline Drought stress & Papaver somniferum & Morphine alkaloids [60] \\
\hline Light irradiation & Artemisia annua & Artemisin [61] \\
\hline UV-B light & Catharanthus roseus & Vinblastine, Vincristine [62] \\
\hline UV-C irradiation & Vitis vinifera & Stilbene [63, 64] \\
\hline UV-B & Hordeum vulgare & Flavonoids [65] \\
\hline White light & Cucumis sativus & Polyamines [66] \\
\hline Light irradiation & Taxus cuspidate & Taxol and baccatin III [67] \\
\hline Ozone $\left(\mathrm{O}_{3}\right)$ & Melastoma malabathric & Anthocyanins [68] \\
\hline
\end{tabular}


Table 3:Effects of salinity on the production of active phyto constituents in medicinal plants

\begin{tabular}{cc}
\hline Plant Species & Compounds \\
\hline Lycopersicon esculentum & Sorbitol, Jasmonic acid [70] \\
\hline Hordeum vulgare & Flavonoids [71] \\
\hline Sesamum indicum & GABA [72] \\
\hline Cakile maritima & Polyphenol [73] \\
\hline
\end{tabular}

\subsubsection{Chemical Elicitors}

Metals (heavy) are mainly used as abiotic elicitor agents in living organisms. They are most commonly used in various fields like agro-technology, industries, high bioaccumulation and toxicity study [74]. Metals (Ni, $\mathrm{Ag}, \mathrm{Fe}$ and $\mathrm{Co}$ ) have been shown to enhance the production of secondary metabolites in different verities of the plants [75].

\subsubsection{Hormonal Elicitors}

Different plant growth regulators have been used in hormonal elicitation studies. Some plants defense molecules such as jasmonic acid (its derivative), salicylic acid (its derivative), cytokinin, Gibberellin GA3 and Ethylene are used as hormonal elicitors for the production of secondary metabolites in the plants.

Table 4:Effects of Chemical elicitors on the production of active phytoconstituents in medicinal plants

\begin{tabular}{|c|c|c|}
\hline Chemical Elicitors & Plant species & Compounds \\
\hline \multirow{3}{*}{$\mathrm{Ag}$} & $\begin{array}{l}\text { Perovskia } \\
\text { abrotanoides }\end{array}$ & $\begin{array}{c}\text { Cryptotanshinone and } \\
\text { tanshinone IIA [76] }\end{array}$ \\
\hline & Vitis vinifera & Resveratrol [74] \\
\hline & Salvia castanea & Tanshinone [77] \\
\hline $\mathrm{Cd}$ & Vitis vinifera & Resveratrol [74] \\
\hline \multirow[b]{2}{*}{$\mathrm{Cu}$} & Ammi majus & Xanthotoxin [78] \\
\hline & Datura stramonium & Sesquiterpenoid [79] \\
\hline $\mathrm{AgNO}_{3}$ or $\mathrm{CdCl}_{2}$ & Brugmansia candida & Scopolamine and Hyoscyamine [80] \\
\hline Rare-earth metal (lanthanum) & Taxus sp & Taxol [81] \\
\hline $\mathrm{Cu}^{2}$ & Amaranthus caudatus & Betacyanins [82] \\
\hline $\mathrm{Zn}^{27}$ & Lepidium sativum & Lepidine [83] \\
\hline $\mathrm{Cu}^{2+}$ & Beta vulgaris & Betalains [84] \\
\hline $\mathrm{Cu}^{2+}, \mathrm{Cd}^{2+}$ & Brassica juncea & $35 \%$ increase in oil content [85] \\
\hline $\mathrm{CuSO}_{4}$ & Dioscorea bulbifera & Diosgenin [86] \\
\hline $\mathrm{Al}^{\top+}, \mathrm{Cr}^{3+}, \mathrm{Co}^{2 \tau}, \mathrm{Ni}^{2+}, \mathrm{Cu}^{2+}, \mathrm{Zn}^{2 \tau}, \mathrm{Cd}^{2}$ & Datura stramonium & Sesquiterpenoid, Lubimin, 3-hydroxylubimin $[87,79]$ \\
\hline Vanadate & Panax ginseng & Ginsenoside [88] \\
\hline
\end{tabular}

Table 5:Effects of the hormonal elicitors on the production of secondary metabolites in medicinal plants

\begin{tabular}{|c|c|c|}
\hline Elicitors & Plant species & Compounds \\
\hline \multirow{4}{*}{ Jasmonic Acid } & Vitis vinifera & Resveratrol [89] \\
\hline & Calendula officinalis & Oleanolic acid [90] \\
\hline & Plumbago indica & Plumbagin [91] \\
\hline & Plumbago rosea & Plumbagin [92] \\
\hline \multirow{4}{*}{ Methyl jasmonate } & Silybum marianum & silybine A\&B [93] \\
\hline & Salvia miltiorrhiza & Tanshinone [94] \\
\hline & Perovskia abrotanoides & Cryptotanshinone and tanshinone IIA [95] \\
\hline & Andrographis paniculata & Andrographolide [96] \\
\hline \multirow{3}{*}{ Jasmonates } & Gymnema sylvestre & gymnemic acid [97] \\
\hline & P. ginseng & Ginsenosides [99] \\
\hline & Mentha piperita & rosmarinic acid [98] \\
\hline \multirow{7}{*}{ Salicylic acid } & Linum album & Podophyllotoxin [100] \\
\hline & Withania somnifera & Withanolides [101] \\
\hline & Brugmansia candida & tropane alkaloids [102] \\
\hline & Azadirachta Indica & Azadirachtin [103] \\
\hline & Salvia miltiorrhiza & Tanshinone [104] \\
\hline & Digitalis purpurea & Digitoxin [105] \\
\hline & Gymnema sylvestre & Gymnemic acid [97] \\
\hline Sodium salicylate & Salvia officinalis & Carnosol [106] \\
\hline \multirow{2}{*}{ Gibberelic acid } & Salvia miltiorrhiza & Tanshinones[107] \\
\hline & Echinacea pupurea & Caffeic acid derivatives [108] \\
\hline
\end{tabular}




\subsection{Biotic elicitors}

They are derived from plant source, microbial source and herbivore constituents. So these are derived from the biological originated elicitors such as exogenous elicitors (fungi, bacteria, virus and herbivore infection). It is also originated from endogenous elicitors (generated in the plant by the action of enzyme of the pathogen) [80]. Yeast cell wall, mycelia cell wall, fungal cell wall are a complex composition of biotic elicitors. It contains a lot of phyto active components which elicitate the plant defense responses. Biotic elicitors also have defined composition of elicitors which includes ergosterol, glycoprotein, $\beta$-glucan, $\mathrm{N}$-acetylglucosamine oligomers and chitin. Yeast extract is the example of biotic elicitors which is used to increase the production of tanshinone in Salvia miltiorrhia by ten times [109]. Dried cell powder of Phoma species is used for elicitation of Inophyllum in the Calophyllum inophyllum by 751 times [110]. Cyclodexin is used for the elicitation of Aamalicine in Catharanthus roseus by three times [111]. Fungi derived cerebroside is used to enhance the production of Artimisnin in Artemisia annua by 2.6 times [112]. Yeast extract is used to enhance the production of isoflavonoids in Pueraria candollei by 4.5 times [113]. Chitosan is used to enhance production of arteminisin in Artemisia annua by six times [114]. Pectin is used to increase the production of Anthocyanins in Vitis Vinifera by 2.5 times [115]. Chitosan is used to increase the production of isoflavonoids in Puerariavar mirifica by 2.1 times [116], to increase the production of Phenylethanoid glycosides in Cistanche deserticola by 3.4 times [117], to increase Azadirachtin in Azadirachta indica by 2.8 times [118] and to increase oleanolic acid in Calendula officinalis by 5 times [90]. Yeast is used to increase the concentration of andrographolide in Andrographis paniculata by 8.82 times [119]. Alginate is used to increase concentration of Anthocyanins in Vitis vinifera by 2.6 times [115]. Aspergillum niger cell wall is used increase hypericin in Hypericum perforatum by 4.2 times [120]. Piriformospora indica culture filtrate is used to increase Betulinic acid in Lantana camara by 7.8 times [121]. Dried powder of polyancora globosa and Xylaria species are used to increase concentration of Gymnemic acid by 10.7 times [122]. The biotic elicitors are further categorized such as plant based elicitors, fungal derived elicitors, bacteria derived elicitors, animal derived elicitors and algae derived elicitors.

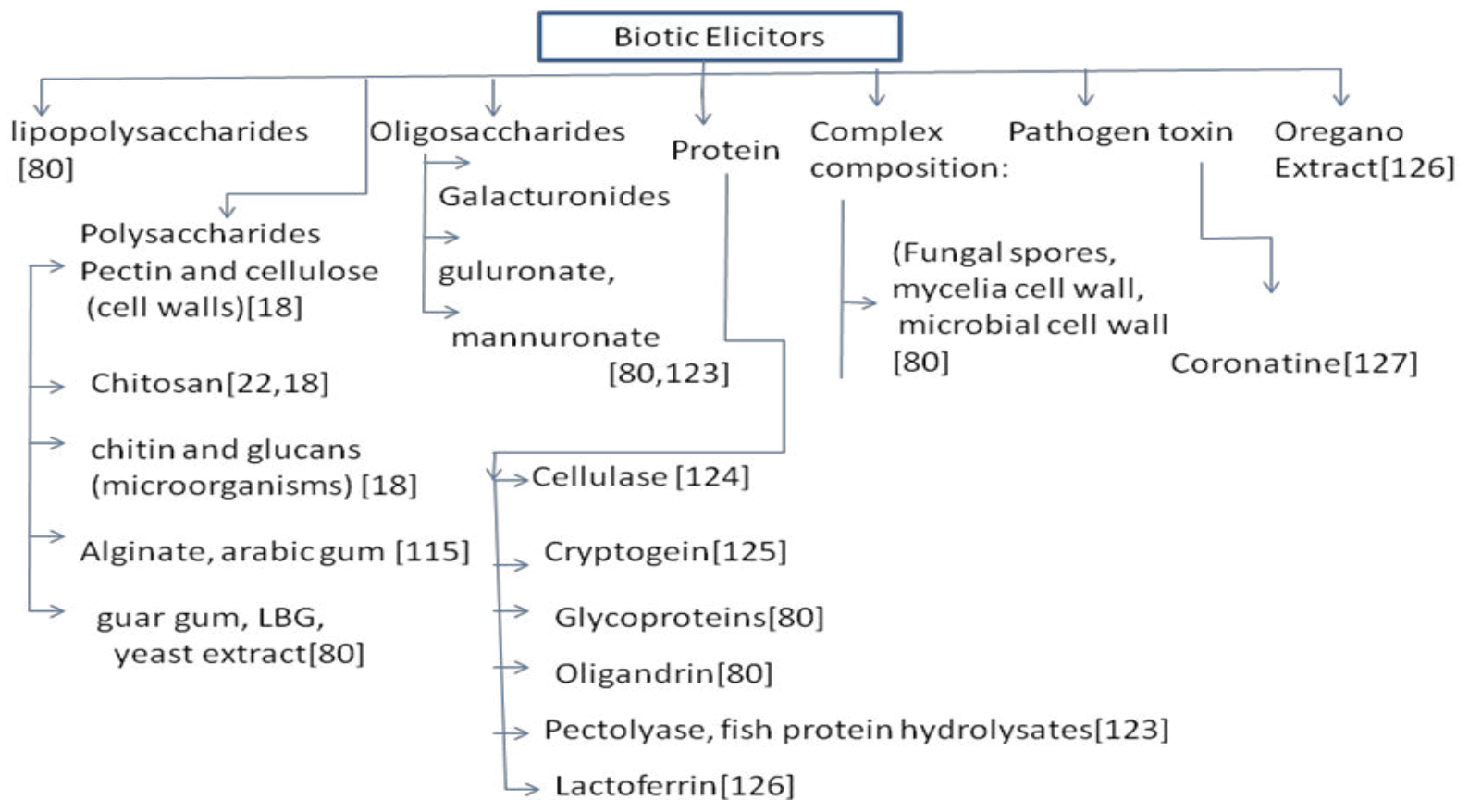

Fig. 2:Classification of Biotic elicitors

\subsubsection{Plant based elicitors}

Polysaccharide and cellulose both are the plant based elicitors which are mainly present in the cell walls (primary) of the plants. Pectin is a type of polysaccharide which comes under defined composition of biotic elicitors. Pectin is mainly found in the citrus fruits. They stimulate the biosynthesis of a lot of secondary metabolites in the plant cells $[90,115]$. 
Table 6:Plant based elicitors used for enhancing the production in plant cells

\begin{tabular}{ccc}
\hline Elicitors & Culture & Metabolites \\
\hline $\begin{array}{c}\text { B-linked } \\
\text { glucopyranosyl }\end{array}$ & Glycine max & Phytoalexins \\
\hline $\begin{array}{c}\alpha-1,4- \\
\text { oligogalacturonide }\end{array}$ & Glycine max & Phytoalexins \\
\hline Chitosan & $\begin{array}{l}\text { N. tobaccum, } \\
\text { E.califomaica }\end{array}$ & Phytoalexins \\
\hline
\end{tabular}

Table 7:Effects of proteins for enhancing the production of secondary metabolites

\begin{tabular}{ccc}
\hline Elicitors & Plant species & Compounds \\
\hline Cellulase & $\begin{array}{c}\text { Nicotiana } \\
\text { tabacum }\end{array}$ & Phytoalexins [87] \\
\hline \multirow{2}{*}{ Yeast cell } & $\begin{array}{c}\text { Eschscholzia } \\
\text { californica }\end{array}$ & $\begin{array}{c}\text { Benzophenanthridine } \\
{[128,129]}\end{array}$ \\
\hline Glycoprotein & $\begin{array}{c}\text { Plantanus } \\
\text { acerifolia }\end{array}$ & Coumarin [130] \\
\hline
\end{tabular}

\subsubsection{Fungal derived elicitor}

Polysaccharide fractions [131], chitosan [132], fungal derived protein [133], mycelia homogenate [134] and culture filtrate [135] are derived from fungal elicitors and they are plant pathogen in nature. Protomyces gravidus is a elicitor which is used to enhance three fold of thiarubrine in the hair root culture of ambrosia artimissiifolia [136]. Trichoderma atroviride D16 is isolated from Salvia miltiorrhiza which is used to increase the concentration of tanshinone I and tanshinone IIA [131]. Mycelium and polysaccharide are used to increase the biomass and tanshinones in hair root culture of Salviya miltiorrhiza [137]. Dry cell powder of Penicillium notatum is used as elicitor for increasing the production of betalain in hairy roots of Beta vulgaris by 2.6 times [138]. Some other elicitors are derived from yeast which are used to enhance the production of secondary metabolites such as camptothecin [139], cardenolide [140], plumbagin [141], scopolamine [142], silymarin [143] andrographolide [144], and rosmarinic acid [145]. Carbohydrate elicitors are used to enhance the phenolic contents (such as rosmarinic acid and lithospermic acid B) in the hair root culture of Salviya miltiorrhiza by 1.3 and 0.2 times respectively [146].

Table 8:Effect of fungal elicitors for the production of secondary metabolite production

\begin{tabular}{|c|c|c|}
\hline Elicitors & Plant species & Compound \\
\hline Glomus mosseae Trichoderma harzianum & Andrographis paniculata & Andrographolide [147] \\
\hline Azotobacter, Azospirillum & Curcuma longa & Curcumin [148] \\
\hline Fusarium oxysporum, Botrytis cinerea & Hypericum perforatum & $\begin{array}{c}\text { Phenylpropanoid and } \\
\text { Naphtodianthrone [149] }\end{array}$ \\
\hline Dioscorea deltoidea & Rhizopus arrhizus & Steroid (Diosgenin) [150] \\
\hline Aspergillus niger & Ocimum basilicum & Rosmarinic acid [151] \\
\hline Rhizoctonia solani & Hyoscyamus muticus & Sesquiterpenes [152] \\
\hline $\begin{array}{c}\text { Aspergillus niger, Coriolus versicolor, } \\
\text { Ganoderma lucidum }\end{array}$ & Rhodiola sachalinensis & Salidroside [153] \\
\hline Verticillium albo-atrum & Medicago sativa & Phytoalexins [154] \\
\hline
\end{tabular}

\subsubsection{Bacteria derived elicitors}

They are derived from the bacterial cell wall and its filtrate of cell homogenate. They are used for the production of secondary metabolites in the plant cells [155]. Bacteria elicitors are used to enhance the concentration of scopolamine in hairy root culture in Scopolia parviflora. It occurs by the inhibition the expression of hyoscyamine 6b-hydroxylase $(\mathrm{H} 6 \mathrm{H})$. Dry cell powder of lactobacillus casei enhances the production of betalain in Lactobacillus casei by 1.38 times.

\section{MECHANISM OF ACTION OF ELICITORS}

Each plant cell has Defense response system which is capable to produce defense responses against pathogens, elicitors or environmental stresses. This defense response in plant cell is determined by their genetic characteristic and physiological state. In most common cases, plant resists to some diseases because it is genetically controlled by plant resistance genes and pathogen avirulent avirulence (Avr) genes [156]. However defenses responses in plant cell is not always produced by avirulent avirulence (Avr) genes but it can be activated by defense responses in cultivars or elicitors responses in major plant species [156]. Initially, elicitors or pathogens stimulate the receptors which are present in the plasma membrane of the plant cell [157]. Pathogens or elicitors produce stress in the receptors of plasma membrane of the plant cell. So during stress some defense molecules gets generated in the plant cells 
like reactive oxygen species (ROS), reactive nitrogen species (RNS), defense-related genes etc. Along with it, changes in plasma membrane potential and enhancement of the chlorine anionic ion and potassium cationic efflux and calcium cationic influx, rapid changes in lipid oxidation, changes in protein phosphorylation, structural defense barriers like that reinforcement and lignifications deposition in cell wall etc. and activation of De-novo biosynthesis of transcription factors also occurs which regulates the expression of genes which are involved in the secondary metabolites production in the plant cell [158-160].

\section{APPLICATIONS OF ELICITORS IN PLANT TISSUE CULTURE IN THE VARIOUS FIELDS OF RESEARCH [161]}

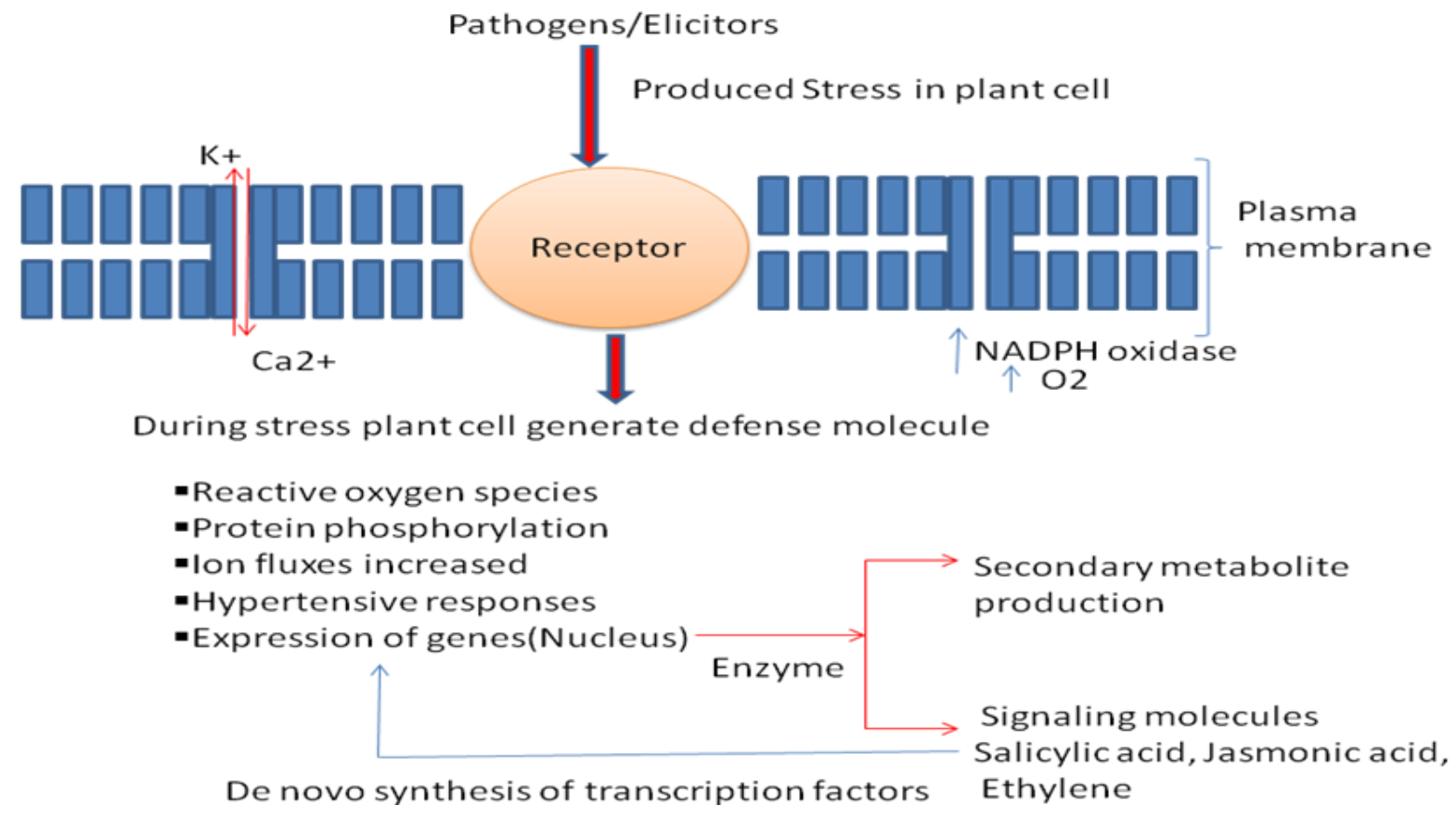

Fig. 3:general mechanism of action of Elicitors application

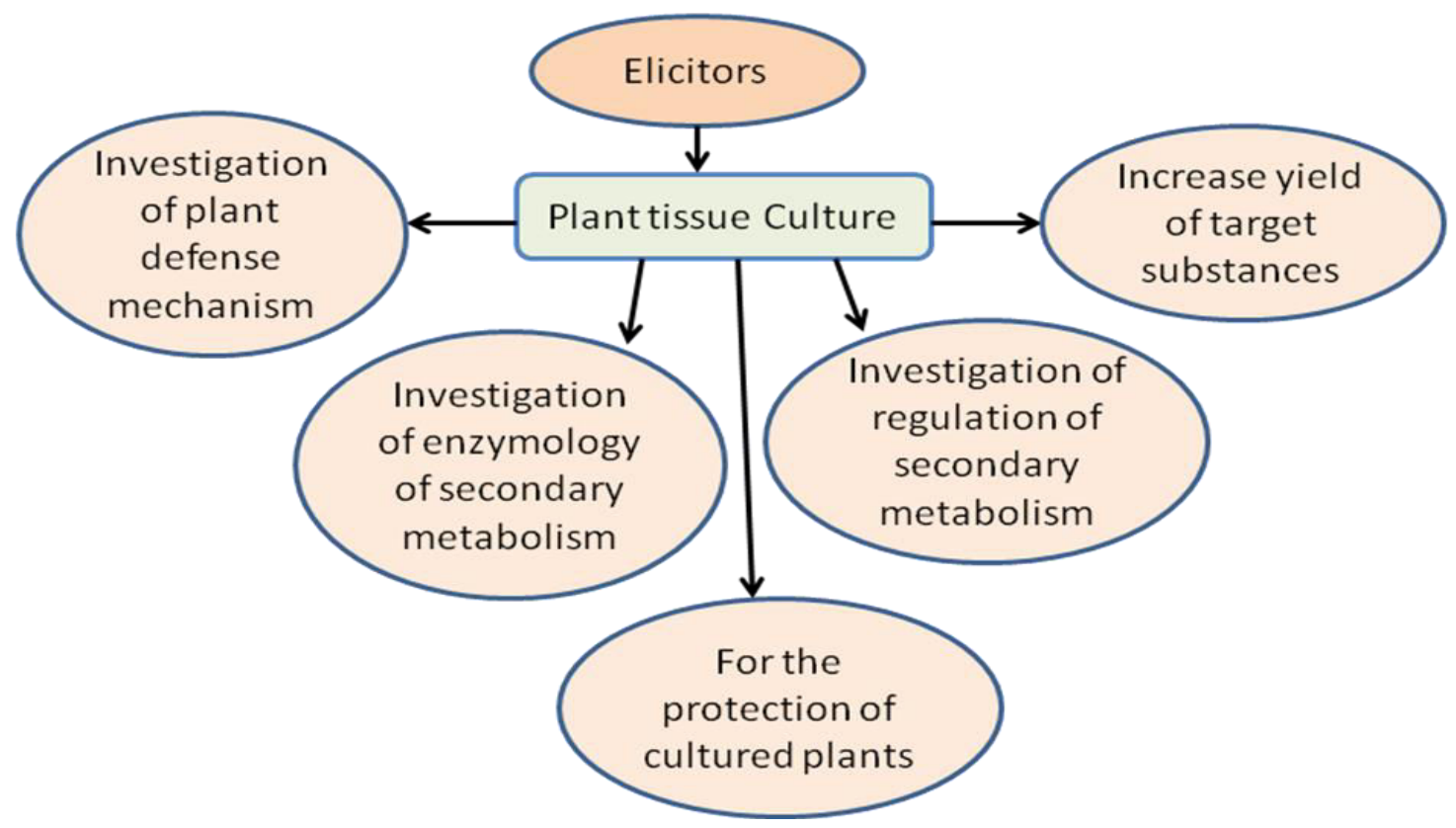

Fig. 4:Application of elicitors in plant tissue culture in various field of researc 
4.1. Effects of elicitors on the elicitation of different phyto-active constituents in the plants

Chemical elicitors are sprayed on the plants cells for the production of target bioactive compounds by the signal transduction pathway and expression of genes which requires transcription factors [162].

Table 9:Some chemical constituents enhanced by elicitors

\begin{tabular}{ccc}
\hline & Phenolic Compounds & \\
\hline Elicitors & Plant & Compounds \\
\hline Ethephon & "Fuji" apples & Anthocyanins , and flavonols [163] \\
\hline Chitosan & Greek oregano & Phenolic acids and Flavonoids [164] \\
\hline CO2 & Strawberry fruits & Anthocyanin and Flavonols [165] \\
\hline Folin acid and vitamin C & Pea sprouts & Total phenolic Compounds [166] \\
\hline NaCl & Radish sprouts & Total phenolics [167] \\
\hline Gethyljasmonate Jasmonate Sucrose & Glucosinolates & Glucosinolates [168] \\
\hline Sucrose & Brassica & Total Glucosinolates [169] \\
\hline Sucrose and mannitol & Broccoli sprouts & Total Glucosinolates: $>50 \%[170]$ \\
\hline
\end{tabular}

\section{CONCLUSION}

Medicinal plants are abundantly available throughout the world. Medicinal plants are now more focused than ever because they have the capability of producing many benefits to society indeed to mankind, especially in the line of medicine. Medicinal plants, herbs and spices are known to Ayurveda since long time. Medicinal plants have wider applications in the field of pharmaceuticals, cosmetics, agriculture and food industries. Herbal medicines play important role in maintaining human health and it also covers a major area of the Indian healthcare system. Active phytoconstituents can be used in the treatment of different types of diseases because they have very few side effects on the body. So it is used as the first choice of drug in the treatment of different types of dreadful diseases [171]. Herbs are used in alternative traditional system of medicines and they are the most common source of medicines in different countries. Herbs are also used as nutraceuticals, cosmeceutical and are also used for enhancing good health for facing chronic stress and it is also used to treat weakness or illness. Various plant and animal species are adversely affected by the various factors, mainly the climatic ones. These factors affect the herbs quality and yields of active phyto-constituents present in the herbs. Some endangered plants are medicinally important because they contain a lot of active phytoconstituents. Some biotechnological methods are used to enhance their productivity and also preserve beneficial effects of medicinally important herbs [171]. Biotechnological techniques like Plant tissue culture technology are majorly used for growing the medicinally active herbs which contain some active phytoconstituents which have therapeutic value. This can be done by using elicitors, precursors, and biotransformation or by changing the medium and environmental conditions. Abiotic and biotic elicitors play an important role for enhancing the active phytoconstituent's synthesis by different biosynthetic pathways in the herbs or plants. They also enhance the synthesis of commercially beneficial compounds. When any stress is produced in a plant by using elicitors then active phytoconstituents are released due to triggering of the defense response [172]. Elicitors are used for the elicitation of secondary metabolites such as alkaloids, flavonoids, tannins, volatile oils, glycosides etc. These secondary metabolites activities are conformed by their competitiveness, persistence and survival [173].

\section{Conflict of interest}

None declared

\section{REFERENCES}

1. Winter JM, Tang Y. Curr. Opin. Biotechnol, 2012; 23(5):736-743.

2. Yuan H, Ma Q, L Ye, Piao G. Molecules, 2016; 21 (5):559.

3. Nasri H, Baradaran A, Shirzad H, Rafieian-Kopaei M, Int. J. Prev. Med., 2014; 5(12):1487-1499.

4. Atanasov AG, Waltenberger B, Pferschy-Wenzig EM, Linder T, Wawrosch C, Uhrin P. Biotechnol. $A d v, 2015$; 33(8):1582-1614.

5. Rosenthal G. A. Phytochemistry, 1991; 30(4):10551058.

6. Ncube B, Staden JV. Molecules, 2015; 20(7):169812731 . 
7. Sandra G, Anabela R. Intech Open, 2018; chapter 5.

8. Hussein R, El-Anssary AA. Intech Open, 2018; 2:1130.

9. McMurry JE. Cengage Learning Ltd, 2015; 10161046.

10. Kolewe ME, Gaurav V, Roberts SC. Mol. Pharm, 2008; 5(2):243-256.

11. Yue W, Ming QL, Lin B, Rahman K, Zheng CJ, Han T et al. Crit. Rev. Biotechnol, 2016; 36(2):215232.

12. Yeole MP, Gholse YN, Gurunani SG, Dhole SM, Int. J. Med. Appl. Sci, 2016; 5(1):16-24.

13. Brown DW, Thorpe TA. World J. Microbiol. Biotechnol, 1995; 11:409-415.

14. Chandran H, Meena M, Tansukh Barupal, Sharma K. Biotechnology Reports, 2020; 26:e00450.

15. Diamond A, Desgagne-Penix I. Plant Biotechnol J, 2016; 14:1319-1328.

16. Goel MK, Mehrotra S, Kukreja AK. Appl Biochem Biotechnol, 2011; 165:1342-1355.

17. Namdeo A. Pharmacogn Rev, 2007; 1:69-79.

18. Radman R, Saez T, Bucke C, Keshavarz T. Biotechnol. Appl. Biochem, 2003; 37:91-102.

19. Rodziewicz P, Swarcewicz B, Chmielewska K, Wojakowska A, Stobiecki M. Acta Physiol Plant, 2014; 36:1-19.

20. Dörnenburg H, Knorr D. Enzyme and Microb. Technol, 1995; 17(8):674-684.

21. Suvarnalatha G, Rajendran L, Ravishankar GA, Venkataraman LV. Biotechnol. Lett, 1994, 16(12):1275-1280.

22. Poulev A, O’Neal JM, Logendra S, Pouleva RB, Timeva V, Garvey AS et al. J. Med. Chem, 2003; 46:2542-2547.

23. Dinh SQ, Joyce DC, Irving DE, Wearing AH. Australas. Plant Pathol, 2008; 37:87-94.

24. Treutter D. Int. J. Mol. Sci; 2010; 11:807-857.

25. Rohwer CL, Erwin JE. J. Hortic. Sci. Biotechnol, 2008; 83:283-304.

26. Tomás-Barberán FA, Loaiza-Velarde J, Bonfanti A, Saltveit ME. J. Am. Soc. Hortic. Sci, 1997; 122:399. 404.

27. Treutter D. Int. J. Mol. Sci, 2010; 11:807-857.

28. Cai Z, Riedel H, Saw NMMT, Mewis I, Reineke K, Knorr D et al. Process Biochem, 2011b; 46(7):14111416.

29. Gueven A, Knorr D. J Food Eng, 2011; 103:237243.

30. Ye H, Huang LL, De CS, Zhong JJ. Biotechnol Bioeng, 2004; 88:788-795.
31. Cai Z, Knorr D, Smetanska I. Enzyme Microb Technol, 2012b; 50:29-34.

32. Saw NMMT, Riedel, Cai Z. Plant Cell Tissue Organ Cult, 2012; 108:47-54.

33. Wu J, Lin L. Appl Microbiol Biotechnol, 2003; 62:151-155

34. Lin L. Wu J. Biotechnol Bioeng, 2002; 78:81-88.

35. Komaraiah P, Kishor PBK, Carlsson M. Plant Sci, 2005; 168:1337-1344.

36. Wang JW, Zheng LP, Wuc JY. Nitric Oxide, 2006; 15(4):351-358.

37. Kang D, Zhang H, Zeng Q. Acta Physiol Plant, 2011; 33:717-16.

38. Cetin ES. Cetin Biological Research, 2014; 47:37.

39. $\mathrm{Ku} \mathrm{KL}$, Chang PS, Cheng YC. J Agric Food Chem, 2005; 53:3877-3881.

40. Yousefzadi M, Sharifi M. Behmanesh M. Plant Physiol Biochem, 2012; 56:41-46.

41. Chan LK, Koay SS, Boey PL. Biol Res, 2010; 43:127-135.

42. Liu CZ, Cheng XY. Plant Cell Rep, 2008; 27(2):357-362.

43. Kehie M, Kumaria S, Tandon P. Bioprocess Biosyst Eng, 2014; 37(6):1055-1063.

44. Gupta P, Sharma S, Saxena S. Appl Biochem Biotechnol, 2015; 176(3):863-874.

45. Gabbiesh A, Kleinwächter M, Selmar D. Jordan J Biol Sci, 2015; 8(1):1-10.

46. Al-Khayri JM, Ibraheem Y. Emir J Food Agric, 2014; 26(11):921-933.

47. Xu Y, Du H, Huang B. Crop Sci, 2013; 53:16261635.

48. Rao SR, Ravishankar GA. Biotechnol Adv, 2002; 20(2):101-153.

49. Zhong JJ, Yoshida T. J Ferment Bioeng, 1993; 76(6):530-531.

50. Zhang W, Seki M, Furusaki S. Plant Sci, 1997; 127(2):207-214.

51. Yu K, Niranjana MH, Hahn E, Paek K. Bio-chemical Engineering Journal, 2005; 23:53-56.

52. Jochum GM, Mudge KW, Thomas RB. American Journal of Botany, 2007; 94:819-826.

53. Zobayed SMA, Afreen F, Kozai T. Plant Physiology and Biochemistry, 2005; 43:977-984.

54. Zhao Y, Qi L, Wei-Ming WW, Saxena PK, ChunZhao LC. Journal of Pineal Research, 2011; 50:83-88.

55. Nadeau P, Delaney S, Chouinard L. Plant Physiology, 1987; 8:73-77.

56. Larson RA. Phytochemistry, 1988; 27:969-978. 
57. Pavlik M, Vacek J, Klejdus B, Kuban V. Journal of Agricultural and Food Chemistry, 2007; 55:6147-6153.

58. Pratibha G, Satyawati S, Sanjay S. Applied Biochemistry and Biotechnology, 2015; 176(3):863874.

59. Liu H, Wang X, Wang D, Zou Z, Liang Z. Industrial Crops and Products, 2011; 33:84-88.

60. Szabo B, Tyihak E, Szabo LG, Botz L. Acta Botanica Hungarica, 2003; 45:409-417.

61. Liu CZ, Guo C, Wang Y, Ouyang F. Process Biochemistry, 2002; 38:581-585.

62. Bernard YKB, Christie AMP, Jacqueline VS, KaYiu S. Biotechnology Progress, 2009; 25:8615.

63. Wang W, Tang K, Yang HR, Wen PF, Zhang P, Wang HL, et al. Plant Physiology and Biochemistry, 2010; 48:142-152.

64. Liu W, Liu CY, Yang CX, Wang LJ, Li SH. Food Chemistry, 2010; 122:475-481

65. Liu L., Gitz Dennis III C, McClure Jerry W. Physiologia Plantarum, 1995; 93:734-738.

66. Kramer GF, Norman HA, Krizek DT, Mirecki RM. Phytochemistry, 1991; 30:2101-2108.

67. Fett-Neto AG, Pennington JJ, Di Cosmo F. Journal of Plant Physiology, 1995; 146:584-590.

68. Chan LK, Koay SS, Boey PL, Bhatt A. Biological Research, 2010; 43:127-135.

69. Sun J, Xiao J, Wang X. Biotechnol Lett, 2012; 34:563-569.

70. Tari I, Kiss G, Deer AK, Csiszar J, Erdei L, Galle A. Biologia Plantarum, 2010; 54:677-683.

71. Ali R, Abbas HM. Plant Soil Environ, 2003; 49:158162.

72. Bor M, Seckin B, Ozgur R, Yilmaz O, Ozdemir F, Turkan I. Acta Physiologia Plantarum, 2009; 31:655659.

73. Ksouri R, Megdiche W, Debez A, Falleh H, Grignon C, Abdelly C. Plant Physiology and Biochemistry, 2007; 45:244-249.

74. Cai Z, Kastell A, Speiser C, Smetanska I. Applied Biochemistry and Biotechnology, 2013; 171:330-340.

75. Zhao J, Zhu W, Hu Q. Enzyme and Microbial Technology, 2001; 28:666-672.

76. Arehzoo Z, Christina S, Florian G, Parvaneh A, Javad A, Seyed HM, et al. Industrial Crops and Products, 2015; 67:97-102.

77. Li B, Wang B, Li H, Peng L, Ru M, Liang Z, Yan X, Zhu Y. Protoplasma, 2016; 253(1):87-100.

78. Purohit M, Pande D, Datta A, Srivastava PS. Planta Medica, 1995; 61:481-482.
79. Furze JM, Rhodes MJC, Parr AJ, Robins RJ, Withehead IM, Threlfall DR. Plant Cell Reports, 1991; 10(3):111-114.

80. Angelova Z, Georgiev S, Roos W. Biotechnol. Equip, 2006; 20:72-83.

81. Pitta-Alvarez S, Spollansky T, Giulietti A. Enzyme Microb Technol, 2000; 26:252-258.

82. Obrenovic S. Plant Physiology and Biochemistry, 1990; 28:639-646.

83. Saba PD, Iqbal M, Srivastava PS. Biologia Plantarum, 2000; 43:253-256.

84. Trejo-Tapia G, Jimenez-Aparicio A, RodriguezMonroy M, De Jesus-Sanchez A, Gutierrez-Lopez G. Plant Cell Tissue and Organ Culture, 2001; 67:1923.

85. Singh S, Sinha S. Ecotoxicology and Environmental Safety, 2005; 62:118-127.

86. Narula A, Kumar S, Srivastava PS. Plant Cell Reports, 2005; 24:250-254.

87. Threlfall DR, Whitehead IM, Biochemical Society Transactions, 1988; 16:71-75.

88. Huang C, Qian ZG, Zhong JJ. J Biotechnol, 2013; 165:30-36.

89. Santamaria AR, Innocenti M. Mulinacci N. J Agric Food Chem, 2012; 60:11135-11142.

90. Wiktorowska E, Długosz M, Janiszowska W. Microb Technol, 2010; 46:14-20.

91. Gangopadhyay M, Dewanjee S, Bhattacharya S. Journal of Bioscience and Bioengineering, 2011; 111:706-710.

92. Silja PK, Gisha GP, Satheeshkumar K. Plant Cell Tissue and Organ Culture, 2014; 119:469-477.

93. Gabr AMM, Ghareeb HE, Shabrawi HMJ. Genet Eng Biotechnol, 2016; 14:327-333.

94. Tassoni A, Durante L, Ferri M. Journal of Plant Physiology, 2012; 169:775-781.

95. Arehzoo Z, Christina S, Florian G, Parvaneh A, Javad A, Seyed HM, et al. Industrial Crops and Products, 2015; 67:97-102.

96. Sharma SN, Jhaa Z, Sinhab RK, Gedac AK. Physiologia Plantarum, 2015; 153:221-229.

97. Chodisetti B, Rao K, Gandi S. Biol-Plant, 2015; 51:88-92.

98. Krzyzanowska J, Czubacka A, Pecio L. Tissue Organ Cult, 2011; 108:73-81.

99. Thanh NT, Murthy HN, Yu KW. Appl Microbiol Biotechnol, 2005; 67:197-201.

100. Yousefzadi M, Sharifi M, Behmanesh M. Biotechnol Lett, 2010; 32:1739-1743. 
101. Sivanandhan G, Kapil Dev G, Jeyaraj M. Plant Cell Tissue Organ Cult, 2013; 114:121-129.

102. Pitta-Alvarez S, Spollansky T, Giulietti A. Enzyme Microb Technol, 2000; 26:252-258.

103. Satdive RK, Fulzele DP, Eapen S. J Biotechnol, 2007; 128:281-289.

104. Xiaolong H, Min S, Lijie C, Chao X, Yanjie Z, Guoyin K. Biotechnology and Applied Bio-chemistry, 2015; 62(1):24-31.

105. Patil JG, Ahire ML, Nitnaware KM, Panda S, Bhatt VP, Kishor PB, et al. Applied Microbiology and Biotechnology, 2013; 97:2379-2393.

106. Krac un-Kolarevic' M, Dmitrovic' S, Filipovic' B, Peric' M, Mis 'ic' D. Simonovic' A, Todorovic S. Biotechnology Letters, 2015; 37(8):1693-1701.

107. Yuan Y, Huang L, Cui GH, Mao Y, He X. Chinese Journal of Experimental Traditional Medical Formulae, 2008; 14:1-3.

108. Abbasi BH, Stiles AR, Saxena PK, Liu CZ. Applied Biochemistry and Biotechnology, 2012; 168(7):20572066.

109. Zhao JL, Zhou LG, Wu JY. Appl Microbiol Biotechnol, 2010a; 87:137-144.

110. Pawar KD, Yadav AV, Shouche YS. Plant Cell Tissue Organ Cult, 2011; 106:345-352.

111. Almagro L, Lo'pez Perez A, Pedreno M A. Biotechnol Lett, 2011; 33:381-385.

112. Wang JW, Zheng LP, Zhang B. Appl Microbiol Biotechnol, 2009; 85:285-292.

113. Udomsuk L, Jarukamjorn K, Tanaka H. Biotechnol Lett, 2011; 33:369-374.

114. Putalun W., Luealon W, De-Eknamkul W., Biotechnol Lett, 2007; 29:1143-1146.

115. Cai Z, Kastell A, Mewis I. Plant Cell, Tissue Organ Cult, 2012a; 108:401-409.

116. Korsangruang S, Soonthornchareonnon N, Chintapakorn Y. Plant Cell Tissue Organ Cult, 2010; 103:333-342.

117. Cheng XY, Zhou HY, Cui X. J Biotechnol, 2006; 121:253-260.

118. Prakash G, Srivastava AK. Biochem Eng J, 2008; 40:218-226.

119. Gandi S, Rao K, Chodisetti B. Appl Biochem Biotechnol, 2012; 168:1729-1738.

120. Xu M, Dong J, Zhu M. Plant Physiol, 2005; 139:991-998.

121. Kumar P, Chaturvedi R, Sundar D. Plant Cell Tissue Organ Cult, 2016; 125:23-29.

122. Netala VR, Kotakadi VS, Gaddam SA. Biotech, 2016, 6(2):232.
123. Kobayashi A, Tai A, Kanzaki H, Kawazu K. Z. Naturforsch, 1993, 48c:575-579.

124. Ma C. Biotechnol. Lett, 2008; 30:961-965.

125. Mikes V, Milat ML, Ponchet M, Ricci P, Blein, JP. FEBS Lett. 1997; 416:190-192.

126. Randhir R, Lin YT, Shetty K. Process Biochem, 2004; 39:637-646.

127. Onrubia M, Moyano E, Bonfill M, Cusidó RM, Goossens A, Palazón J. J. Plant Physiol, 2013; 170:211-219.

128. Roos W, Evers S, Hieke M, Tschope M, Schumann B. Plant Physiology, 1998; 118:349-364.

129. Farber K, Schumann B, Miersch O, Roos W. Phytochemistry, 2003; 62:491-500.

130. Alami I, Mari S, Clerivet A. Phytochemistry, 1998; 48:771-776.

131. Ming Q, Han T, Li W. Phytomedicine, 2012; 19:330-333.

132. Conrath U, Domard A, Kauss H. Plant Cell Rep, 1989; 8:152-155.

133. Baillieul F, Genetat I, Kopp M. Plant J, 1995; 8:551-560.

134. Zhao J, Zhu WH, Hu Q. Enzyme Microb Technol, 2001b; 28:666-672.

135. Kumar V, Rajauria G, Sahai V. Process Biochem, 2012; 47:901-907.

136. Bhagwath SG, Hjortsø MA. J Biotechnol, 2000; 80:159-167.

137. Ming Q, Su C, Zheng C. J Exp Bot, 2013; 64:56875694.

138. Savitha BC, Thimmaraju R, Bhagyalakshmi N. Process Biochem, 2006; 41:50-60.

139. Deepthi S, Satheeshkumar K. Tissue Organ Cult, 2016; 124:483-493.

140. Sun L, Su H, Zhu Y, Xu M. Plant Cell Reports, 2012; 31:179-185.

141. Komaraiah P, Naga Amrutha R, Kavi Kishor PB. Enzyme Microb Technol, 2002; 31:634-639.

142. Pitta-Alvarez SI, Spollansky TC, Giullietti AM. Enzyme and Microbial Technology, 2000; 26:252258.

143. Angeles Sa'nchez-Sampedro M, Ferna'ndezTa'rrago J, Corchete P. J Plant Physiol, 2005; 162:1177-1182.

144. Gandi S, Rao K, Chodisetti B. Appl Biochem Biotechnol, 2012; 168:1729-1738.

145. Sahu R, Gangopadhyay M, Dewanjee S. Acta Physiol Plant, 2013; 35:1473-1481.

146. Chen H, Chena F, Chiu FCK. Enzyme Microb Technol, 2001; 28: 100-105. 
147. Arpana J, Bagyaraj DJ. American-Eurasian Journal of Agricultural and Environmental Sciences, 2007; 2:3338.

148. Sena MK, Dass PK. Indian cocoa. Arecanut and Spices Journal, 1998; 21:31-33.

149. Sonja GS, Oliver T, Stéphane M, Alain D, Eric L, Claude J, Daniel H. Plant Cell Tissue and Organ Culture, 2015; 122 (3):649-663.

150. Rokem JS, Schwarzberg J, Goldberg I. Plant Cell Reports, 1984; 3:159-160.

151. Bais HP, Travis S, Herbert PW, Vivanco JM. Plant Physiology and Biochemistry, 2002; 40:983-995.

152. Singh G. Ph.D. Thesis A. Pennsylvania State University, USA.1995.

153. Zhou X, Wu Y, Wang X, Liu B, Xu H. Biological and Pharmaceutical Bulletin, 2007; 30(3):439-442.

154. Walton TJ, Cooke CJ, Newton RP, Smith CJ. Cellular Signaling, 1993; 5(3):345-356.

155. Jung HY, Kang SM, Kang Y. Enzyme Microb Technol, 2003; 33:987-990.

156. García-Brugger A, Lamotte O, Vandelle E, Bourque S, Lecourieux D, Poinssot B, et al. Mol. Plant Microbe. Interact, 2006; 19:711-724.

157. Montesano M, Brader G, Palva ET. Mol. Plant Pathol, 2003; 4:73-79.

158. Ferrari S. Adv. Exp. Med. Biol, 2010; 698:152-166.

159. Smetanska I.:Ph.D. Thesis, University of Berlin, Berlin, Germany, 2005.
160. Zhao JL, Zhou LG, Wu JY. Appl Microbiol Biotechnol, 2010a; 87:137-144.

161. Veersham C. In Elicitation: Madicinal Plant Biotechnology, CBS Publisher, India, 2004; 270-293.

162. Zhao J, Davis LC, Verpoorte R. Biotechnol. Adv, 2005; 23:283-333.

163. Li Z, Gemma H, Iwahori S. Sci. Hortic, 2002; 94:193-199.

164. Yin H, Fretté XC, Christensen LP, Grevsen K. J. Agric. Food Chem, 2011; 60:136-143.

165. Wang SY, Bunce JA, Maas JL. J. Agric. Food Chem, 2003; 51:4315-4320.

166. Burguieres E, McCue P, Kwon YI, Shetty K. Bioresour. Technol, 2007; 98:1393-1404.

167. Yuan G, Wang X, Guo R, Wang Q. Food Chem, 2010; 121:1014-1019.

168. Baenas N, García-Viguera C, Moreno DA. J. Agric. Food Chem, 2014; 62:1881-1889.

169. Guo R, Yuan G, Wang Q. Food Chem, 2011; 129:1080-1087.

170. Guo R, Yuan G, Wang Q. Sci. Hortic, 2011; 128:159-165.

171. Gairola S, J Medicinal Plants Research, 2010; 4(18):1825-1829.

172. Patel H, Krishnamurthy R, J Pharmacognosy and Phytochemistry, 2013; 2:61-65.

173. Namdeo AG, Ph.D. Thesis, Devi Ahilya Vishwavidyalaya, Indore, M.P. India. 2004. 